\title{
Design Attributes for Adaptive Tool's Innovation in Rehabilitation Setting: A Scoping Research
}

\author{
Nurhikma Mat Yusof, Raja Ahmad Azmeer Raja Ahmad Effendi, Ahmad Zamir Che Daud
}

\begin{abstract}
Innovation in rehabilitation represents creative design which involve adaptive tool (AT) for patients in the occupational therapy department. Earlier, an online survey on innovative activities among $O T$ has been conducted on thirty Malaysian occupational therapists. Findings indicate that $80 \%$ of the occupational therapists innovate new tools during rehabilitation. The purpose of this study is to identify design attributes of AT as issues highlighting the low rate of AT usage based on several factors; non-compliance, uncomfortable design, insufficient instruction and training, and also due to user's personality i.e. lack of personal acceptance and confidence in using AT. A scoping review of 20 relevant literatures related to the usage, effectiveness and barriers of AT are drawn widely from the rehabilitation journal in the period between 1968 2018, and from design psychology journals to support the findings. A summary of each themes that has been highlighted from this review are AT prescribe factors, AT equipment factors and AT education factors. This review suggests that future research for creative activities in rehabilitation shall be provided with design consideration in order to bring better AT creation. The implications of these findings for the effects of innovation are discussed.
\end{abstract}

Keywords: Adaptive tool, design, innovation, rehabilitation.

\section{INTRODUCTION}

The definition of design is related to the process of planning, creating and making for technical role while innovation is the ability to execute new ideas, method or device including the growth of variations in products, processes and market. Both are strongly related as the result shows the ability of an organization perceived and encourage new knowledge to be transformable into new products and processes. Both definitions are regularly being used interchangeably, however, they are different in focus. Creativity in creation releases the potential of new ideas, but innovation introduces change into relatively stable systems. Being thought as experiments, creation can be the sources of designing an appropriate solution in innovation that can be measured. Everyone has the potential to get involved in the process of creation and innovation. Notable, the designers are the one who exposed to the design thinking and process, which are the common methods for innovation. Recently,

Revised Manuscript Received on September 14, 2019.

Nurhikma Mat Yusof, Department of Industrial Design, Universiti Putra Malaysia, Selangor, Malaysia \& Department of Industrial Design, Universiti Teknologi MARA, Selangor, Malaysia. (Email: hikmamy@gmail.com.my)

Raja Ahmad Azmeer Raja Ahmad Effendi*, Department of Industria Design, Universiti Putra Malaysia, Selangor, Malaysia. (Email: azmeer@upm.edu.my)

Ahmad Zamir Che Daud, Centre of Occupational Therapy, Universiti Teknologi MARA, Selangor, Malaysia. (Email: zamir_1225@yahoo.com.my.) creative and innovative activities are popular among other professionals and expert-users in certain fields. With zero knowledge on designing, what are the consequences of future creations?

Ideally, in 1920's, Joseph Schumpeter first introduced the classic innovation in business terms. Under the umbrella of business-led innovation, there are four attributes listedcreation of new markets, new methods of production and transportation, new forms of industrial organisations and new kinds of consumer goods. These activities are translated as entrepreneurial activities. How are these attributes related to the design field? The last criteria (new kinds of consumer goods) listed plays a big impact in design innovation. The quality of consumer good offers new feelings and experiences which may be a token in introducing other kind of opportunities and ideas that adding value to the activities [1]. In order to achieve those activities, it involves design, constructs within the components of creative thinking, resourcefulness, planning forethought and continuous compensatory action.

Innovation in rehabilitation setting requires individual capability, education and training. In healthcare, it is as an introduction of new information systems, treatment and work practices which represents different intensity of difficulty [2]. There is no formal or direct information on how to guide them in creating (AT), except several topics in their practices that relates to design such as ergonomic and purpose of adaptive device as part of the rehabilitation process.

Adaptive or assistive tool is referred as a tool, equipment or a system that is modified or applied to the needs of patient's occupation in guiding and improve their ability of functional body parts or system based on The Assistive Technology Act of 2004. AT usually involves low and medium technology. It functions as an assessment or intervention prescription towards a patient's recovery from certain disability or dysfunction. The innovation of AT is aim to connect a person's limited ability with the environment and their tasks via decreasing the impact of deficiencies [3].

It is used to suit patient's limitation and abilities either for patient's assessment or intervention. For the inpatient, most of the AT are used at the rehabilitation hospital or centre, but are only applicable in certain duration of use. AT is being suggested in various ways including the implementation of Assistive Technology (AT) [3], usercentered design approach [4], 


\section{DESIGN ATTRIBUTES FOR ADAPTIVE TOOL'S INNOVATION IN REHABILITATION SETTING: A SCOPING RESEARCH}

mHealth application, sensors [5] and even telerehabilitation [5], [6] that use to be introduced as nonface-to-face rehabilitation treatment. At times, patient and care taker are advised to self-made it creatively to the closest functions due to the high price of the tools in market. However, for all the AT's innovations made, in [3] stated few reasons for unused of it including the malfunctioning of the device, poor instructions, not suitable with the patient's need and low of aesthetic appearance in which past research [3], [7], [11] has highlighted to be the influence on an individual's level of comfort in using an AT.

Therefore, it is necessary to evaluate a prescribed AT in order to achieve an effective recovery of a patient in the future. This review also highlights on the cause and factors that contribute to the ineffective development of rehabilitation tools to the patient. Then continuing on how the selected design approaches impact variables that might be used to find innovation changes in the therapists' knowledge.

\section{METHODOLOGY}

This methodology extends the existing reviews of the usage, effectiveness and barriers of AT which are drawn widely from the rehabilitation journal in the period between 1970's - 2018, and the design psychology journal to support the findings. A total of 20 selected studies were reviewed randomly between the period to analyse the factors of unused prescribed AT. All these studies were conducted in the United States, Canada and other parts of the world involving participants as young as children to geriatric with various diagnostic categories such as cerebral palsy, cardiac, neurological pathology, orthopedic deficit, lower limb amputation, chronic lower back pain and mixed disabilities. The prescribed AT ranged from low to high technology which include toileting system, grooming and bathing aids, floor sitting activity, virtual reality technology, mobility and communication devices.

\section{A Search Strategy}

Literatures are searched in each of the following databases: Scopus, PubMed and MEDLINE. The search was conducted using the following keywords and terms: "assistive technology" OR "assistive device" OR "rehabilitation tools" OR "creation" OR "innovation" AND "usage" AND "effectiveness" AND "barriers". After the search of databases, about 4,658 articles were identified. Using the limitation and exclusion criteria of years (from year 2000 to 2019) and selected keyword such as "rehabilitation", "occupational therapy" and "nursing", 39 articles remained. Next, the search used PubMed that applies the same keywords which resulted with 1,994 articles. Other members of research contribute with 12 related articles.

\section{B Qualitative Synthesis}

After the databases search, exclusion and duplication, 106 articles were identified. 32 articles were considered for qualitative synthesis. From this process, 20 articles were included in this scoping review (see Fig. 1).

\section{Prisma Flow Diagram}

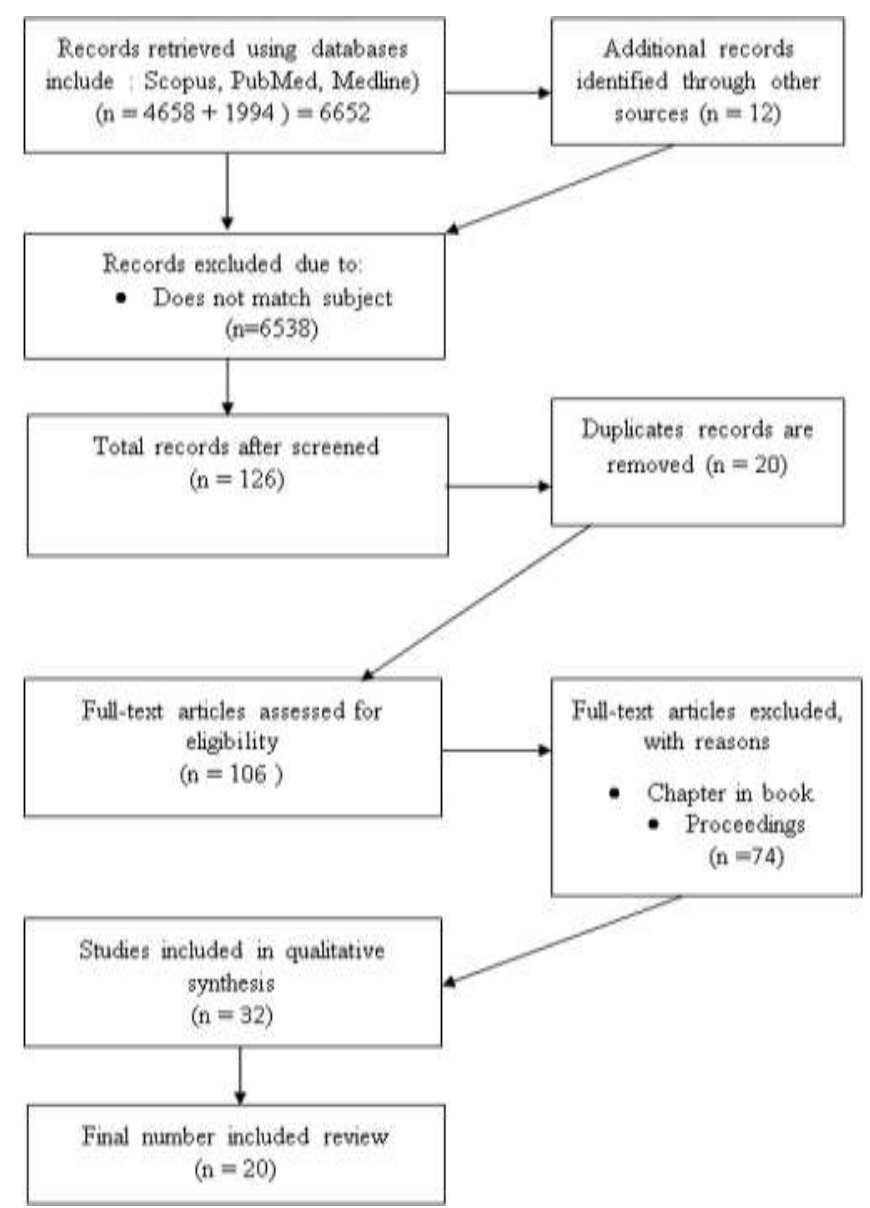

Fig. 1. Prisma flow diagram

\section{Inclusion and Exclusion Criteria}

Articles were considered and were included to be reviewed if they were written in English, and were published between 2000 until 2018. Other sources of article which were published in 1970's was also considered due to the origins of the issue that had occurred since then. The review articles were most probably discussing on the usage, effectiveness and barriers of AT among the patient. Articles were excluded if they discussed only on certain technology on particular rehabilitation cases.

\section{RESULTS AND DISCUSSION}

The usage of $\mathrm{AT}$ in the literature review reported in various conditions. Table 1-3 provide a summary of the information which all the AT being categorized in three themes; AT prescribe factors, AT equipment factors and AT education factors. Characteristics highlighted as:

Characteristic (n), $\mathrm{n}=$ frequency of article mentioned

\section{A AT Prescribed Factors}

The category of assistive tool involves self-care amenities, furniture, cookery tools, home and environment adaptations. The literature review shows some results for the therapist to consider before prescribing patients with the AT. 
Table- 1: AT prescribed factors

\begin{tabular}{|c|l|l|}
\hline Adaptive Tool & \multicolumn{1}{|c|}{ Purpose } & \multicolumn{1}{c|}{ Result } \\
\hline Flip2Sit & $\begin{array}{l}\text { Activity for floor and } \\
\text { table-level activities for } \\
\text { children with cerebral } \\
\text { palsy }\end{array}$ & $\begin{array}{l}\text { Clinically significant } \\
\text { but need } \\
\text { modification }\end{array}$ \\
\hline $\begin{array}{c}\text { Toileting system } \\
\text { /aids }\end{array}$ & $\begin{array}{l}\text { adaptation in the } \\
\text { bathroom }\end{array}$ & $\begin{array}{l}15 \% \text { non-use, 46\% } \\
\text { discontinue at home }\end{array}$ \\
\hline Virtual reality & to retrain ADL & $\begin{array}{l}\text { Clinically significant } \\
\text { but cost effective }\end{array}$ \\
\hline Mobility & to retrain ADL & $\begin{array}{l}\text { Further research of } \\
\text { post treatment for } \\
\text { elderly }\end{array}$ \\
\hline Self-care & to retrain ADL & $\begin{array}{l}\text { Further research of } \\
\text { post treatment for } \\
\text { elderly }\end{array}$ \\
\hline High-tech \\
devices & to identify current & $\begin{array}{l}\text { Future appropriate } \\
\text { model and team } \\
\text { assessment process }\end{array}$ \\
\hline $\begin{array}{c}\text { Special } \\
\text { Education }\end{array}$ & $\begin{array}{l}\text { adriers to its integration } \\
\text { classroom }\end{array}$ & $\begin{array}{l}\text { Equipment } \\
\text { suitability, adequate } \\
\text { training }\end{array}$ \\
\hline to retrain ADL & $\begin{array}{l}\text { Students experience } \\
\text { immediate benefits } \\
\text { for their function in } \\
\text { everyday school } \\
\text { activities }\end{array}$ \\
\hline
\end{tabular}

According to the results, it is important to understand more on the patient's routine, suitability of material, and home programs. Under AT prescribed factors, characteristics highlighted are routine (8), material (7), suitability (7) and experience (8). It is recommended that further study to be conducted in more detail to determine the impact of creativity towards occupational therapist's ability in designing AT. The purpose of using creativity to create wellness or to enhance their ability within self can be determined through the effectiveness of innovated AT [2].

\section{B AT Equipment Factors}

The problems and features of existing AT were examined in the literature review. Issue of low usage rate has also been highlighted. It has been mentioned that the issue derives from the equipment itself of being uncomfortable and lack aesthetic features [3], [7], [10]. Contrary to design studies, product appearance plays a big role in anticipating the use of the user. It comes in package of user-centered design, good functions, colours, material and cost. These factors may need to be applied in shaping the rehabilitation reputation. Characteristics that are extracted under this theme which are to be considered in future creations of AT are typicality of the AT design (6), safe (5) and apply suitable technology (8) for the patients.

Table- 2: AT prescribed factors

\begin{tabular}{|c|c|c|}
\hline Adaptive Tool & $\begin{array}{c}\text { Characteristic (n), } \\
\text { n=Frequency of Article } \\
\text { Mentioned }\end{array}$ & Comments \\
\hline $\begin{array}{c}\text { Floor sitting } \\
\text { activities }\end{array}$ & $1(5 \%)$ & $\begin{array}{c}\text { not stable, preferred } \\
\text { to be mobile }\end{array}$ \\
\hline $\begin{array}{c}\text { Toileting and } \\
\text { grooming }\end{array}$ & $5(25 \%)$ & $\begin{array}{c}\text { consider patient's } \\
\text { environment, } \\
\text { routines }\end{array}$ \\
\hline Virtual reality & $1(5 \%)$ & too high technology \\
\hline Mobility & $3(15 \%)$ & $\begin{array}{c}\text { features do not fit } \\
\text { user characteristic }\end{array}$ \\
\hline Self-care & $5(5 \%)$ & $\begin{array}{c}\text { features do not fit } \\
\text { user characteristic }\end{array}$ \\
\hline $\begin{array}{c}\text { High-tech } \\
\text { devices }\end{array}$ & $1(5 \%)$ & $\begin{array}{c}\text { difficulties in } \\
\text { managing equipment }\end{array}$ \\
\hline Communication & $1(5 \%)$ & $\begin{array}{c}\text { features do not fit } \\
\text { user characteristic }\end{array}$ \\
\hline
\end{tabular}

\begin{tabular}{|c|c|c|}
\hline Adaptive Tool & $\begin{array}{c}\text { Characteristic (n), } \\
\text { n=Frequency of Article } \\
\text { Mentioned }\end{array}$ & Comments \\
\hline $\begin{array}{c}\text { Special } \\
\text { Education }\end{array}$ & $3(15 \%)$ & $\begin{array}{c}\text { alternative products } \\
\text { to fit learning } \\
\text { environment }\end{array}$ \\
\hline
\end{tabular}

\section{AT Education Factors}

Some of the AT prescribed only works at the rehabilitation setting, but not for home use after the patient is discharged from the ward. Training and education of the usage of AT is being emphasized as a whole. Inadequate AT instructions and information also decrease the low rate of usage. There is a need to improvise the future services in the health system as information and education of individuals hold the supports for the wellness perspective [11]. What makes an Assistive Technology innovative and competitive, is not only its product and technical processes, but also the intrinsic characteristics of the induced experience, including the role of assisting and encouraging the rehabilitation process [12]. For this theme, creation of AT must also consider the knowledge of the persons involve in rehabilitation (4), training for them (5) and observation from the therapist (4).

Table- 3: AT education factors

\begin{tabular}{|c|c|c|}
\hline Adaptive Tool & $\begin{array}{c}\text { Characteristic (n), } \\
\text { n=Frequency of Article } \\
\text { Mentioned }\end{array}$ & Comments \\
\hline $\begin{array}{c}\text { Floor sitting } \\
\text { activities }\end{array}$ & $1(5 \%)$ & $\begin{array}{c}\text { therapist, parents } \\
\text { observation }\end{array}$ \\
\hline $\begin{array}{c}\text { Toileting and } \\
\text { grooming }\end{array}$ & $5(25 \%)$ & patient's training \\
\hline Virtual reality & $1(5 \%)$ & $\begin{array}{c}\text { therapist observation, } \\
\text { patient's assessment }\end{array}$ \\
\hline Mobility & $3(15 \%)$ & patient's training \\
\hline Self-care & $5(5 \%)$ & patient's training \\
\hline $\begin{array}{c}\text { High-tech } \\
\text { devices }\end{array}$ & $1(5 \%)$ & $\begin{array}{c}\text { therapist observation, } \\
\text { patient's assessment }\end{array}$ \\
\hline Communication & $1(5 \%)$ & patient's training \\
\hline $\begin{array}{c}\text { Special } \\
\text { Education }\end{array}$ & $3(15 \%)$ & $\begin{array}{c}\text { patient's training, } \\
\text { therapist, parents } \\
\text { observation }\end{array}$ \\
\hline
\end{tabular}

\section{CONCLUSION}

This study has identified a number of connections between AT and prescribed factors as design attributes in rehabilitation setting. Existing AT in market holds a lot of options but upon cases, the ability of patients is varying that urge customization. The findings suggested a crosscollaboration between rehabilitation and design as issues of low rate AT usage which is highlighted based on the equipment itself. In the practical approach to the integration of responsible innovation, design thinking and design process are needed and being supported by other design models. It would be fruitful to pursue further research about the creation of AT in rehabilitation in order to lead OT's understanding in the relationship of prescribed AT and patient's behavior that can be a benefit to rehabilitation as a whole.

The characteristics and needs show a clear message that

Published By:

Blue Eyes Intelligence Engineering \& Sciences Publication 


\section{DESIGN ATTRIBUTES FOR ADAPTIVE TOOL'S INNOVATION IN REHABILITATION SETTING: A SCOPING RESEARCH}

the creation of AT has to be observed as early as the process of the creation in order to improve the effectiveness of the rehabilitation session. This shall focus on the OT since they are the one who spend much time with the patients, and they have to come out with the innovated tool to suit certain assessment or intervention. They have the ability to solve clinical issue but have difficulty in making it function properly. A scholar [14] in his study suggests OT are ideal figure to assist the knowledge transition (KT) for clinical purposes between clinical populations with their educational ability in both clinical and research approaches.

For health sciences, the literature is plentiful but studies generally emphasize on the role of science and technology in innovation. In fact, the understanding of the adoption involving technology remains a poorly understood phenomenon [15]. It is crucial for OT to have understanding on the interaction of needs between the patient and caretaker during the adaptation process as it helps much on the effectiveness of the outcome [16].

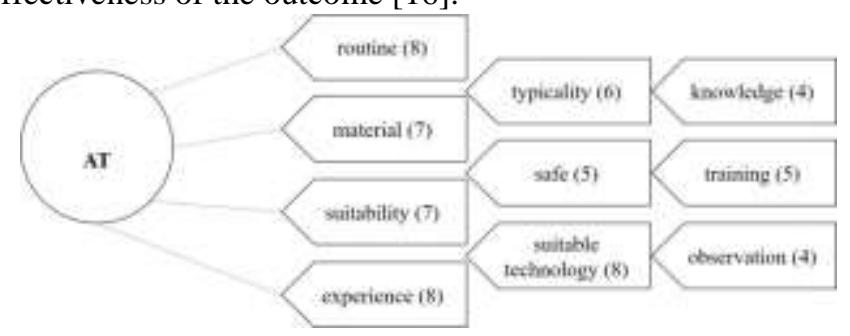

Fig. 2. Overall attributes

\section{RECCOMMENDATIONS}

In future, it is suggested that design element consideration should be compulsory in designing AT. This is because a good design does not just exist but works. OT has to find way to enhance the skills of creativity in order to maintain the good service for the disabled. It is a method that can be value for the complexity of the adaptation process [10]. It is crucial to form an interdisciplinary collaboration between design and other fields as design is capable of transforming sustainable future living through innovative product and practice. It is a part of the new practice of design and research which brings the user together in the process of design development [8], [17], [18] co-design is seen as the new paradigm of future facilitation of collaboration in translating the design attributes into effective AT design in rehabilitation [9].

\section{REFERENCES}

1. A. D. Sood. (2011, Sept 19). What is the relationship between innovation and design? [Online]. Available: http://www.designpublic.in/2011/09/19/what-is-therelationship-between-innovation-and-design/.

2. C. Keller, K. Gäre, M. Edenius, and S. Lindblad, "Designing for complex innovations in health care: Design theory and realist evaluation combined," ACM 4th International Conference on Design Science Research in Information Systems and Technology, 2009, pp. 1-11.

3. L. N. Gitlin, R. Levine, and C. Geiger, "Adaptive device use by older adults with mixed disabilities," Archives of Physical Medicine and Rehabilitation, 74(2), 1993, pp. 149-152.

4. A. G. Money, J. Barnett, J. Kuljis, M. P. Craven, J. L. Martin, and T. Young, "The role of the user within the medical device design and development process: Medical device manufacturers' perspectives," BMC Medical Informatics and Decision Making, 11(1), 2011, pp. 1-12.

5. I. Dimbwadyo-Terrer, S. Pérez-Nombela, A. De los Reyes-Guzmán, and A. Gil-Agudo, "New perspectives in occupational therapy," in Advances in Occupational Therapy Research, L. R. Sherman, Ed. New York: Nova Science Publishers, 2014, pp. 51-65.

6. A. Soundy, L. Pidgeon, T. Pelton, and A. Soundy, "Determining the use and value of social support in Telerehabiliation Interventions for individuals with Multiple Sclerosis: A narrative synthesis review," Journal of Novel Physiotherapy and Rehabilitation, 1, 2017, pp. 120-136.

7. T. Wielandt and J. Strong, "Compliance with prescribed adaptive equipment: A literature review," British Journal of Occupational Therapy, 63(2), 2000, pp. 65-75.

8. A. Pirinen, "The barriers and enablers of co-design for services," International Journal of Design, 10(3), 2016, pp. $27-42$.

9. C. Ernst and A. Moore, The nature of creativity in occupational therapy: Views of US occupational therapists. Master thesis, Washington: University of Puget Sound, 2013.

10. J. Copley and J. Ziviani, "Barriers to the use of assistive technology for children with multiple disabilities," Occupational Therapy International, 11(4), 2004, pp. 229-243.

11. M. I. Merican, Y. Rohaizat, and S. Haniza, "Developing the Malaysian health system to meet the challenges of the future," Medical Journal of Malaysia, 59(1), 2004, pp. 84-93.

12. S. S. V. Mallin and H. G. de Carvalho, "Assistive technology and user-centered design: Emotion as element for innovation," Procedia Manufacturing, 3, 2015, pp. $5570-5578$

13. D. N. Naumann. (2013). Occupational therapists as knowledge brokers: Leading knowledge translation in primary care. [Online]. Available: http://search.ebscohost.com/login.aspx?direct=true\&db= $\operatorname{cin} 20 \& \mathrm{AN}=107836584 \&$ site $=$ ehost-live

14. J. S. Farias, T. A. Guimarães, and E. R. Vargas, "Innovation in hospitals in Brazil and Spain: Managers perceptions about the patient's electronic medical record," Brazilian Business Review, 9(3), 2012, pp. 25 46.

15. R. S. Cardoso, A. I. D. Silva Filho, and L. V. Vieira, "The co-production of innovation: A case study in a rehabilitation hospital," Revista de Administração Mackenzie, 17(4), 2016, pp. 109-129.

16. L. Kimbell. (2009). Design practices in design thinking. [Online]. Available: http://www.lucykimbell.com/stuff/DesignPractices_Kim bell.pdf.

17. B. Mager, "Service design," in Design Dictionary: Perspectives on Design Terminology, M. Erlhoff and T. Marshall, Eds. Basel: Birkhäuser, 2008, pp. 354-357.

\section{AUTHORS PROFILE}

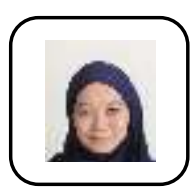

Nurhikma Mat Yusof is a Master holder from University Teknologi Mara (UiTM) Shah Alam, Malaysia in Industrial Design studies and currently a $\mathrm{PhD}$ student in the same field of Universiti Putra Malaysia.She also a Senior Lecturer at the Department of Industrial Design, Faculty of Art \& Design UiTM Melaka. A member of Life and Emotion (LIEMO) Design research group head by Dr Raja Ahmad Azmeer Raja Ahmad Effendi. Involves in various research study and consultation in industrial design field including furniture design, design with rehabilitation and etc. Her research now is focusing on adaptation design 
for interdisciplinary. Won two innovation competition for design for rehabilitation in 2019

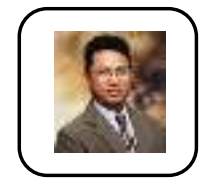

Raja Ahmad Azmeer Raja Ahmad Effendi is a $\mathrm{PhD}$ holder from Swinburne University of Technology (SUT) in Industrial design studies, Affective Product Design/Product Perception. Currently, a Senior Lecturer at the Department of Industrial Design, Faculty of Design and Architecture, Universiti Putra Malaysia. He is the Head of Life and Emotion (LIEMO) Design research group that consists of inter and similar discipline researchers in charge of researching the development of consumer products to achieve sustainable living. With the research group, he also leads other research projects which are supported by the university and industry grant. The robotic project he is currently involved with is a project research that collaborates with the industry for the purpose of producing the first Malaysian iconic humanoid robot that applies the Pictorial Semantic Differential (PSD) and Quality Functional Deployment (QFD) method. Meanwhile, another project involvement of his include the Agrone, which is a collaborative project between UPM's Industrial Design and Aerospace Engineering Department, that designed and produced working prototype drones for agricultural purposes.

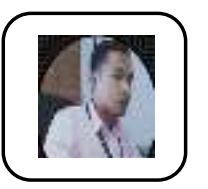

Ahmad Zamir Che Daud is a $\mathrm{PhD}$ holder from James Cook University, Australia in Hand \& Uppe Limb Rehabilitation. Currently, a Senior Lecturer at the Centre of Occupational Therapy, Universiti Teknologi MARA, Selangor, Malaysia. His research interest is related to occupation-based intervention in hand rehabilitation and willing to collaborate with people from other parts of world to enhance occupation based practice. He is also a secretary for Malaysia Occupational Therapy Association (MOTA). Involves in various research and conference of Occupational Therapy in recent years. His research and publications much shared in the Research Gate and much focus on the occupation-based intervention. 